\title{
A Study of Project Management Practices in the Czech Republic
}

\section{Majra Hodžić, Helena Hrůzováa}

\begin{abstract}
The importance of project management has hastily increased and its rapid development and tendency towards innovation has made it one of the key components of organizations' performance. Therefore, the main purpose of this paper was to conduct a systematic study of the current situation and practices in the field of project management in the Czech Republic. Four areas of project management are closely studied: stakeholders' main demands and requests, main characteristics of project management, level of use of project management methods and identification of the characteristics of the respondents. The research has an explanatory character and works with primary and secondary data. Primary data was obtained through an online cross-sectional survey comprising of four parts (identical to the areas studied) conducted in the Czech Republic in 2016. The questionnaire consisted of twenty questions in total and it had elements of both quantitative and qualitative research. It yielded 118 usable responses. The sample examined was random but expert - it covered organizations operating in the Czech Republic and respondents were asked to identify their professionalism and experience in the area of project management. Furthermore, the results of the authors' survey were compared with the results of similar surveys from the last five years providing secondary data. This comparison brought forth additional insights and better understanding of the theoretical grounding. The results showed a prominent relationship and, to some extent, a correlation between understanding (defining) a successful project and identifying success factors, stakeholder demands and problematic areas, displaying a complexity of working in the field of project management. Furthermore, a vaguely-defined scope was identified as the most problematic area and issue influencing project success. Overall, the study indicates the necessity for innovation, such as the development of a basic framework for project governance approaches as well as an increase in the use of available project management methods. These directions will not only improve
\end{abstract}

\footnotetext{
1 Majra Hodžić, Ph.D. Student, University of Economics, Prague, Faculty of Business Administration, Department of Management, W. Churchill Sq. 4, 13067 Prague 3, Czech Republic, e-mail: xhodm08@vse.cz

2 Helena Hrůzová, Assistant Professor, University of Economics, Prague, Faculty of Business Administration, Department of Management, W. Churchill Sq. 4, 13067 Prague 3, Czech Republic, e-mail: hruzova@vse.cz
}

Received 4 September 2017; Revised 25 January 2018, 9 February 2018; Accepted 12 February 2018. 
project management, but will also boost entrepreneurship spirit and help modern, highly potential start-ups to be competitive in the market.

Keywords: project management, project management methods, knowledge, stakeholders.

\section{INTRODUCTION}

Project management is undoubtedly one of the main hot topics within most organizations. It has been increasingly used in various business fields as well as by different entities from start-ups and small companies to multinationals. Project management serves as a very valuable application platform for the entrepreneurial innovation process.

While the substantive content of project management has essentially remained unchanged for the last twenty years, the framework and approach have undergone innovative changes. This corresponds with the view of modern approaches in management which basically means that the essence is not in learning and implementing the methods and software, but in embracing the complex, overall approach of project management. This overall approach also includes project sustainability which is defined by the European Commission as the "likelihood of a continuation in the stream of benefits produced by the project after the period of external support has ended" (European Commission, 2004, p. 146). Sustainable development is even considered as a new management paradigm for managing projects in complex and dynamic environments (Gareis, 2013). The popularity and wide usage of project management have been noticeable in the Czech Republic as well. In the last few years, not only multinational companies, but a wide range of organizations including small start-ups, are orientating more towards project management approaches.

This has resulted in raised interest for the status of project management practices in the Czech Republic among researchers. Since 2012, IPMA CZ and EY (former Ernst \& Young) conducted surveys attaining to get a closer overview and analyze the situation of project management in the Czech Republic. These studies provide a general overview of the situation in project management since 2012 and give us important insights about project teams coping with many issues and unsuccessful projects. However, there are still gaps in the development and elaboration of the topic in research and practice, which shows that there is a great space in project management for more research, especially in the Czech Republic.

With regards to this, the research problem grew out of our interest in the particular topic supported by the above-mentioned gaps. Observing the 
current situation, the research question rose - is it time for a boost in project management in the Czech Republic? In order to properly address and answer the research question, the study that was carried out attained to overcome the limitations of the previous studies by conducting a cross-sectional study with carefully chosen respondents, whose professionalism and knowledge in the area of project management is proven, and at the same time focusing on four specific areas. The research concentrates on the following four areas of project management: stakeholders' main demands and requests, the main characteristics of project management in the Czech Republic, the level of use of the project management methods, and the identification of the characteristics of the respondents.

The choice of these four areas was not incidental but has its rational context:

1) The demanding requirements of the stakeholders at the start of any project as well as the extent of their changes during project execution have a significant (and often a dramatic) impact on the success of the project;

2) Although projects show clear specificities compared to other "tasks," they are internally differentiated. They vary in scope, duration, financial claims, industry, culture, risks and other characteristics or features. If we want to make analysis and comparisons, we must perceive and respect them;

3) Quality is a key focus area in project management. Among the ways to increase it is the application of project management methods which innovate and standardize the direction of management so as to avoid unnecessary factual and procedural non-rationalities and errors, and make communication about the project among the stakeholders more understandable.

Therefore, the main purpose of this paper was to conduct a study of the current practices in the field of project management in the Czech Republic from a multi-factor perspective according to the chosen four areas.

\section{LITERATURE REVIEW}

The following literature review comprises of subsections that provide sufficient theoretical background of the key areas and terms in the field of project management relevant for this paper. Since the paper studies project management, the first subsection focuses on the definitions and necessary explanation for this term. Subsequently, agile approach and projects are defined too. With regards to the four areas being investigated in this paper, the literature review contains the necessary theoretical framework for key elements of these areas as well. Therefore, the role and importance of the project manager as well as project stakeholders and the project life cycle are defined and discussed. 


\section{Project management definition}

There are many project management definitions, but the basis is the same for all of them. With regards to the purpose of this paper being to analyze current project management practices in the Czech Republic, the authors chose four relevant definitions. The first three come from professional Project Management associations. The fourth one comes from an academic guru in Project Management.

Thus, first, the Project Management Institute defines Project Management in its oldest official PMBOK ${ }^{\circledR}$ Guide (PMI, 1996, p. 6) as "the application of knowledge, skills, methods and techniques to project activities in order to meet or exceed stakeholder needs and expectations from a project." The definition is extended in the Guides' third edition (PMI, 2004, p. 8): "Project management is accomplished through the application and integration of the project management processes of initiation, planning, executing, monitoring and controlling, and closing."

The second, the International Project Management Association (IPMA) does not - due to the context of its methodology - logically target its publication (or it deliberately avoids) on a PM definition, but defines the role of a professional manager involved: "Project Management is established as the prominent method for implementing change in the world and project, program and portfolio managers are leading the way (IPMA, 2015, Foreword).

The third, the Office of Government Commerce (OGC), as the best practice method in project management called PRINCE2 ${ }^{\circledR}$, defines project management (OGC 2009, p. 4) as: "the planning, delegating, monitoring and control of all aspects of the project, and the motivation of those involved, to achieve the project objectives within the expected performance targets for time, cost, quality, scope, benefits and risks."

The fourth, and last but not least, is an overview definition of project management expressed by Professor Kerzner (2009, p. 4) as "the planning, organizing, directing, and controlling of company resources for a relatively short-term objective that has been established to complete specific goals and objectives. Furthermore, project management utilizes the systems approach to management by having functional personnel (the vertical hierarchy) assigned to a specific project (the horizontal hierarchy)." Although this definition differs from the first ones in words, the essence of both remains the same.

Following these definitions, this study and paper perceive the project management definition to be from a modern approach in management and not the traditional one. Modern approach in this sense means that project management implementation and practice is not just about learning methods and techniques and using management support programs (application of project management tools and methods), but is also about the complex 
understanding and adoption of a modern, agile and innovative project management approach that involves constant change, innovation and flexibility, as well as a great focus on project managers and project teams.

\section{Agile project management}

It is very important to incorporate an agile approach when defining and understanding the concept of project management. At first, the term agility can be used to define the dynamic and proactive act to constantly change the environment (Owen et al., 2006), and with regards to it, organizational agility can be defined as an organization's ability to be flexible and easily adaptable to changing conditions without those changes being forced (Ali, Chew \& Tang, 2004).

In connection to these general definitions, agile project management can be perceived as practices that are flexible, prone to changes and easily adaptable. These practices, as well as agile project management methods, are derived from, or at least highly influenced by, the agile software development methods (Hanadi, 2014).

The main basis of the agile project management concept are short delivery iterations supported by inevitable continuous learning (Sauer \& Reich, 2009). This approach involves three main steps at the very beginning of the project - streamlined planning, precise requirement definition and solution design (Hanadi, 2014). Once the project has been started, the project team can work in a sequence of iterations that result in a more detailed, precise and realistic planning, design, testing, analysis of requirements as well as execution (Hanadi, 2014).

One of the great advantages of an agile approach is the ability to immediately modify project requirements that are reviewed by short delivery iterations. This allows projects to be more flexible, adaptable and could greatly influence customer satisfaction with a better outcome. An agile approach allows the project team to focus on scope and requirements by prioritizing them according to their importance and value for the customer (Hanadi, 2014).

The involvement of the customer in setting up the scope and requirements of the project is a crucial characteristic of the approach. It enables the project team to identify and focus on highly valued requirements and not to waste time on costly and inefficient requirements that makes no significant difference to the customer (Hanadi, 2014).

The last, but not the least, an agile approach accentuates a collaborative management approach to delivering projects, and comprises of getting customer feedback as well as enabling continuous improvements and enhancements (Hass, 2007). 


\section{Project definition}

Nowadays, projects are very diverse and may have different goals, needs and requirements. In addition to that, there are many different project definitions. Considering the chosen relevant definitions of project management, as well as the authors' intentions to analyze current practices when doing projects in the Czech Republic, this work is based on the definition of a project from the $\mathrm{PMBOK}^{\circledR}$ Guide and a project definition by EY.

"A project is a temporary endeavor undertaken to create a unique product, service, or result" (PMI, 2013, p. 1). EY defines the project as a "one - time process that consists of a set of synchronized and managed activities with a defined start and end date, which is implemented to achieve the goal (taking into account time, cost and resources limitations) and which meets the specific, predefined requirements" (EY Czech Republic, 2015).

The duration of the project is the first key characteristic, because every project must have a start and end date. The uniqueness of the project is another key characteristic (PMI, 2000). The project or service created within the project should be unique in terms of differences from all other products or services in an organization. That uniqueness creates value added, which should be a major outcome of the project.

The precise duration, structure, and organizational levels on which projects are done can be determined by organizations according to their needs and specifics (PMI, 2000). It can be done at one organizational level (an example is a company integration project at top management level) or only in one unit (implementation of a new procedure in the production department), but it may also have an impact on the organization or society as a whole, and/or involve several departments (modernization and implementation of an information system).

The Standish Group International defines a project as successful if it is completed on time, within budget and in line with the originally defined scope. A project that is complete and is "functional" is defined by Standish Group as a problematic project. Projects are considered problematic if the deadline or budget was exceeded and if the scope was only partially fulfilled. If a project is canceled before completion, it is considered as an unsuccessful project (The Standish Group International, 2013).

According to Doležal, et al., 2012, the fulfillment of the Project Management Triangle does not necessarily mean the project was successful. Therefore, in practice, it is essential to use certain success criteria. There are no strictly given success criteria as projects differ in their objectives, content, realization and also have different stakeholders. In addition to these differences, the criteria may be subject to change at different phases of the project. (Roberts, 2007). 
However, there are generally accepted criteria that can be used when determining criteria for a project. Consequently, criteria can be split into three basic groups - the criteria for project owners, typical operating criteria and criteria of other stakeholders, sponsors and suppliers in particular.

Although there is no precise definition and division of projects, they can be distinguished from several points of view. For the purpose of this paper, project area, duration, project costs and success criteria aspects are taken into consideration (Roberts, 2007). In addition to these aspects, there is another important aspect - the division of projects according to the nature of the activities that are being carried out. Thus, phases should be clearly set and distinguished to form the life cycle of the project (Kerzner, 2009).

Project distinction, in terms of the subject of the project, is closely related to areas that should be addressed and managed as a project. As per experience, the following areas are suitable for the implementation of project management:

- development of a new business idea;

- design and implementation of investment, construction, marketing, IT and similar projects;

- market penetration;

- reorganization and restructuring;

- development, reconstruction and improvement of products;

- research projects,

- development and implementation of new technologies.

Projects may also vary by duration (Pritchard, 2009):

- short-term projects with a duration of up to 6 months;

- medium-term projects with a duration of up to one year;

- long-term projects with a duration of more than 12 months.

From the total cost or budget point of view, projects are generally divided into low-cost, medium-cost and high-cost projects. This division depends on the individual determination of the limits (maximum amounts) and can be used for comparison of similar projects or projects in a particular organization (Pritchard, 2009).

\section{Project manager role}

The role of a project manager has changed recently in accordance to the rapidly changing environment, flexibility and uniqueness of projects. In relation to that, demands and requirements for project managers are changing (Kerzner, 2009). Tasks, for which project managers should be responsible, are elaborated in the PRINCE2 ${ }^{\circledR}$ guidance (e.g., OGC, 2009). Expectations of the project manager role focus more on direct management and the management of outputs from the 
project (managing project deliverables) and much less on technical skills and leading the project team in a technical direction (Kerzner, 2009).

One of the reasons is the trend of shared responsibility for tasks and activities which were previously the responsibility of the project manager solely. That means that the expectations and demands of the role of the members of the project team change as well - it is no longer enough to be an expert, but members must also have knowledge of project management (Kerzner, 2009).

Another reason is to see project management as a strategic management of a business unit and, in that case, project managers should not make decisions within the project, but they should also participate in the project strategic decisions (Kerzner, 2009).

Every project manager should have the basic skills and capabilities to ensure the successful fulfillment of the role of the project manager. These are based on the general managerial skills and abilities that the $\mathrm{PMBOK}^{\circledR}$ Guide provides (PMI, 2000):

- leadership;

- communication;

- negotiation;

- ability to solve the problem;

- influence on the organization.

IPMA centers on the continuous development of project manager competencies. In its last competence baseline edition (IPMA, 2015), IPMA redefines the competence elements into three competence areas. The competence area "people" relates to personal and interpersonal competences and comprises of 10 elements. Area "practice" includes technical aspects and encompasses 14 elements. The third area is "perspective" and defines contextual competence embracing 5 elements.

\section{Project stakeholders}

According to many definitions (e.g., Longman \& Mullins, 2005; Kerzner, 2009; SPŘ, 2010 and others), stakeholders are people and organizations that are actively involved in the project and can be positively or negatively affected by the project - its result, certain activities, project realization or its non-realization.

Different projects may have different stakeholders due to different goals and content. However, there are key stakeholders in every project (PMI, 2000). The project manager is the first key stakeholder and can be defined as the individual responsible for managing the project (PMI, 2000). The customer is the first external key stakeholder and represents the individual or organization that will use the project's product (PMI, 2000). Since there are usually more product users, there may be multiple layers of customers too. 
The performing organization is also a key stakeholder as it is the enterprise whose employees are most directly involved in doing work on the project (PMI, 2000). Project team members are the core of the project - the group that performs the work on the project. The project sponsor can be an internal or external stakeholder and can be defined as the individual or group that provides the financial resources for the project.

\section{Project life cycle}

Time management is an important part of project management that can influence the overall success or failure of a project (Fiala, 2004). With regards to it, projects are divided into phases that together form the life cycle of a project (SPŘ, 2010 Fiala, 2004). Because of the uniqueness and different terms of each project, the life cycle is only generally defined and must be specified and defined according to an individual project (Roberts, 2007).

There are three most general phases of the project that can be adjusted to the needs of a particular project (can be further divided) (SPŘ, 2010):

- pre-project phase that indicates the origin of the project and includes feasibility and opportunity studies;

- project phase, which includes initiation, preparation, implementation and project completion;

- after-project phase, which includes the evaluation of the project.

According to the $\mathrm{PMBOK}^{\circledR}$ Guide $(2013$, p. 5), project management is "accomplished through the appropriate application and integration of the 47 logically grouped project management processes, which are categorized into five Process Groups". These groups are namely: Initiating, Planning, Executing, Monitoring and Controlling, and Closing.

\section{Project management in the Czech Republic in the last five years}

Since project management is one of the fields of management that adapts to change rather quickly, it could be possible to develop and improve project management practices within a relatively short period of time. In order to analyze the status of the practices of project management in the Czech Republic, it was necessary to start with an overview of their status in the last five years.

There were few surveys focused on project management in the Czech Republic, and conducted in the last five years that provided a good overview of general project management topics and practices. This served as a starting point for the authors' own research.

Despite the differences in the sample of the compared surveys, the research method, the areas investigated, as well as the targeted respondents, were very similar, if not the same. The purposes and aims are also overlapping. Thus, the results of different surveys (including the authors' own research) 
could be compared and the comparison afterwards brought forth additional insights and a better understanding of the theoretical grounding.

The results of the following surveys were compared: IPMA CZ surveys conducted in 2012 and 2015, EY (former Ernst \& Young) surveys conducted in 2013 and 2015 and the author's survey conducted in 2016 as research for a master's thesis.

When defining a successful project, the respondents of all mentioned surveys agreed that fulfillment of the scope of the project is a key component. Simultaneously, determination of the scope of the project was identified at the same time as one of the main success factors (if done precisely and successfully) and one of the "problem areas" leading to failures of the projects (if not specified precisely and correctly).

The results of the surveys showed steady growth in the number of projects since 2012 and variety in the topics addressed by projects. However, the rate of the unsuccessful projects is still relatively high according to the compared surveys. Consequently, there is a growing need for the application of innovative, more sustainable approaches and methods.

When it comes to methods used, all surveys focused on the most used (most popular) methods and results were different. However, currently used methods in the last five years in all surveys are common methods of the traditional project management. The least used were agile project management methods.

Further details on the surveys conducted in the period of 2012-2015 are summarized in the following two sub-sections.

\section{Surveys conducted in 2012-2013}

As was already mentioned, IPMA CZ (the Czech branch of the International Project Management Association) and EY (Ernst \& Young) conducted two surveys focused on project management in the Czech Republic in the last five years.

The first survey was carried out in 2012 and the aim was to map the status of project management in the Czech Republic (IPMA CZ, 2013). The survey was carried out among project managers, portfolio managers and members of the project teams. It yielded in total 178 responses during a two month period. The method used was an online questionnaire which consisted of 15 research and 8 identification questions. Most of these were closed questions with one possible answer.

The key findings of this survey pointed to the rather unsatisfactory status of project management in 2012 (IPMA CZ, 2013). More than half of the respondents were not involved in any evaluation or analysis of the impacts and benefits of the conducted projects; one third of them were unaware of the exact project budget and whether it was exceeded; $25 \%$ of them were 
unaware of the project schedule; a clear goals set-up was practice for only one third of the respondents, etc. (IPMA CZ, 2013).

At that time, the main reasons for project failure were a lack of qualified and efficient human resources, incorrectly set or unsupervised processes, insufficiently implemented pre-project phase and inflexibility towards changes in project implementation (IPMA CZ, 2013).

The study that followed was conducted one year later by EY and focused on the internal projects of organizations actively involved in project management. In total, subjects from 69 organizations were involved in this study and the results showed a rather similar situation of project management as the previous study by IPMA CZ in 2012 (EY, 2013).

Additional findings from the EY study, relevant for this paper, were the increased number of projects in the Czech Republic at that time, progressing complexity of the projects, as well as expectations and skills from project managers. Moreover, the majority of the projects were from the IT field and $25 \%$ of respondents were involved in projects with duration of more than one year (EY, 2013).

\section{Surveys conducted in $\mathbf{2 0 1 5}$}

As in previous years, IPMA CZ and EY conducted similar studies in 2015. The aim was the same as in the surveys before - to map the status of project management in the Czech Republic and identify its main characteristics. The method and the duration of the survey by IPMA CZ, as well as the questionnaire structure and questions, were the same as in 2012. The total number of respondents was 141 (EY \& PMI CZ, 2016).

The main threats to the success of the projects were mainly pertaining from 2012. The main issue was human resources, where $67 \%$ of the respondents had problems with either overloaded or incompetent team members. Vaguely-defined scope and problems with project planning were another widely present threat, since $55 \%$ of respondents identified these amongst the main threats to the success of the project (EY \& PMI CZ, 2016).

Improvements in the evaluation and analysis of the outcome of the project were noted in the survey conducted in 2015 . Around $60 \%$ of the respondents were either involved in, or at least informed about, the project outcomes (EY \& PMI CZ, 2016).

The approach to the EY 2015 survey was the same as in 2013. The focus was again on the internal projects of organizations actively involved in project management and in total, respondents from 123 organizations participated in this survey (EY \& PMI CZ, 2016).

Similar to 2013, the increase in the number of projects within the organizations was notified. At the same time, there is a decrease in the 
duration of the projects - in comparison to 2013, there is an $11 \%$ decrease in the number of projects longer than one year (EY \& PMI CZ, 2016). At the same time, more than $50 \%$ of the projects were in the IT field, which is the main project management field in the Czech Republic.

Respondents also mentioned the main reasons for project failure and the key ones were problems with project scope, definition and establishment, various, unclear expectations of the project outputs, followed by inadequate risk management and insufficient staffing (EY \& PMI CZ, 2016).

\section{RESEARCH METHODS}

\section{Research approach}

We used the following research process (Khotari, 2004): identification of the research problem, review of the literature, statement of research question and hypothesis, selection of the data collection method, selection of a research sample, analysis and interpretation of data.

The research problem grew out of our interest in the particular topic supported by gaps in development and elaboration of the topic in research and practice. There is a great space in project management for research, especially in the Czech Republic.

In order to address the situation properly, the research concentrates on four areas of project management and the choice was not incidental but has its rational context:

4) The demanding requirements of the stakeholders at the start of any project, as well as the extent to which changes during project execution have any significant (and often dramatic) impact on the success of the project;

5) Although projects show clear specificities compared to other "tasks," they are internally differentiated. They vary in scope, duration, financial claims, industry, culture, risks and other characteristics or features. If we want to make analysis and comparisons, we must perceive and respect them;

6) Quality is one of the major focuses in project management. Among the ways how to increase it, belong the application of project management methods that innovate and standardize the course of management so as to avoid unnecessary factual and procedural non-rationalities and errors, and make communication about the project among the stakeholders more understandable.

Taking into consideration the previously explained context, the following four areas have been chosen: stakeholders' main demands and requests, main characteristics of project management in the Czech Republic, level of use of project management methods and identification of the characteristics of the respondents. 


\section{Methodology}

The study conducted consists of the analysis of primary and secondary data. There are many different methods of data collection and a few of them were used in this paper. On-line databases and scholar websites were used for "desk research" to collect secondary data. The most relevant data gathered were the results of previously conducted studies in the field of project management in the Czech Republic. The main information and results of the studies have been summarized in the previous sections.

It is important to emphasize that despite the differences in the sample of the compared surveys, the research method, areas investigated, as well as the targeted respondents were very similar, if not the same. The purposes and aims are also overlapping, thus, the results of different surveys (including the authors' own research) could have been compared and the comparison afterwards brought forth additional insights and a better understanding of the theoretical grounding

However, the key data for fulfillment of the goals of the study were primary data. In order to have relevant and usable primary data, it is essential to make sure they are valid, accurate, objective and up-to-date; therefore, it is inevitable to conduct your own research.

The questionnaire, as one of the data collection methods, provides information about human knowledge, attitudes, preferences, as well as human behavior. The information provided is primarily descriptive (Kotler \& Keller, 2011). This method can have a structured or unstructured form. If a single list of questions is used, and a there is invariable access for all respondents, then the method used is a structured questionnaire. If, on the other hand, the list of questions and access can vary, this is an unstructured questionnaire (Kotler, 2007). Furthermore, different contact methods can be used for conducting questionnaires - via email, telephone survey, personal interviews, as well as an internet questionnaire (Kotler, 2007).

If the internet questionnaire is chosen as a suitable method, it can provide adequate flexibility and certain control over the sample, in addition to its great advantages of being a very quick and affordable method of data collection as well as having supreme control over personal influence (Tull, et al., 1993). At the same time, it allows the collection of a large amount of data. On the other hand, one of the features of an internet questionnaire is a small, narrow sample frame and a typically lower rate response (Tull, et al., 1993).

Another downside of using this method is keeping the personal data of the respondents, but this may be overcome by creating a questionnaire using web portals that enable the privacy and anonymity of respondents.

While taking into consideration all of the possibilities and features of different methods, as well as the aims and requirements of the study, the 
authors chose an online questionnaire as the most suitable method to conduct the primary research.

This questionnaire has been cross-sectional, comprising of four parts (identical to the areas studied). The questionnaire consisted of twenty questions in total and it had elements of both quantitative and qualitative research. In addition to that, there was a complex matrix used for identification of the project management methods used. Data were collected in the period from March 10th 2016 to May 10th 2016. The focus on the data is given from a managerial perspective.

\section{Research question and hypotheses}

The research questions arise from observing the current situation: is it time for innovation and a boost to project management in the Czech Republic? According to the research question and the purpose, the main premise is as follows:

$\mathrm{H} 1$ Project management in the Czech Republic has been progressing significantly in the last few years.

This premise can be broken into sub-hypotheses upon focus areas studied in this paper:

H1.1 Different stakeholders and their demands and expectations make working in project management more complex.

$\mathrm{H} 1.2$ Project management in the Czech Republic is shifting from a traditional approach towards an innovative, agile approach.

$\mathrm{H} 1.3$ There is an increase in the use of project management methodology (methods).

\section{Research sample}

With regards to the purpose of research, the basic characteristics of the respondents were predetermined and thus, the target group was established according to these characteristics. Broadly, the respondent was a person who had professional experience in the field of project management in the Czech Republic. This means they had been working either as a project manager, project team member, or a member of the Project Management Office (PMO).

Respondents were asked to identify their professionalism via their job position and years of experience on projects as well as their project management qualifications. Respondents who did not prove their expertise were excluded from further analysis.

The authors assumed the most suitable method to address suitable respondents was snowball sampling. It is a non-probability method that enables future recruiting of the respondents after addressing a certain part of the target group. This method is based on approaching subjects whose 
contacts were available to the authors and they could further recruit future suitable subjects among their acquaintances if they would forward the questionnaire.

Furthermore, this method involved a personal approach since the direct email address of the subject was used and authors believed this could influence them positively and increase the willingness of respondents to participate in the research. The collection of the email addresses was done initially by searching for the published data of potential respondents on the websites of large companies in the Czech Republic that are actively involved in project management as well as reaching out to acquaintances who could forward the questionnaire to suitable subjects. The largest number of respondents was generated from a publicly available document of IPMA CZ (Czech branch of the International Project Management Association), "Alphabetical List of Certified Project Managers - certificates issued in years 2001-2015".

The final number of targeted respondents who were addressed was 1010. The survey in the end yielded 118 usable responses, thus, the response rate was $12 \%$. Taking into consideration the specifics of the study as well as the method (online questionnaire), the attained response rate was satisfactory.

\section{RESULTS}

\section{Project success and stakeholder demands}

Respondents could choose factors belonging to three different groups - risk, managerial and human factors. The factors from different groups could have been mixed and the accent was on choosing the main (key) factors. Figure 1 shows the relationship between understanding and defining the successful project and the main success factors that influence project success. The respondents could define the successful projects by following the generally accepted Project Management Triangle. The first option was the most rigorous as the project is considered successful only if it fulfills all three project management constraints - scope, time, and budget. The second option presumes exceeding the budget while fulfilling the scope and time, and the third option assumes exceeding the time, but satisfying the defined scope and budget.

Human factors were determined as the most influential and the majority of respondents chose the most rigorous definition of a successful project too. They included effective communication within and outside the team, a highly-skilled and experienced team and a team sharing the same goals and motivation to attain the best results. 


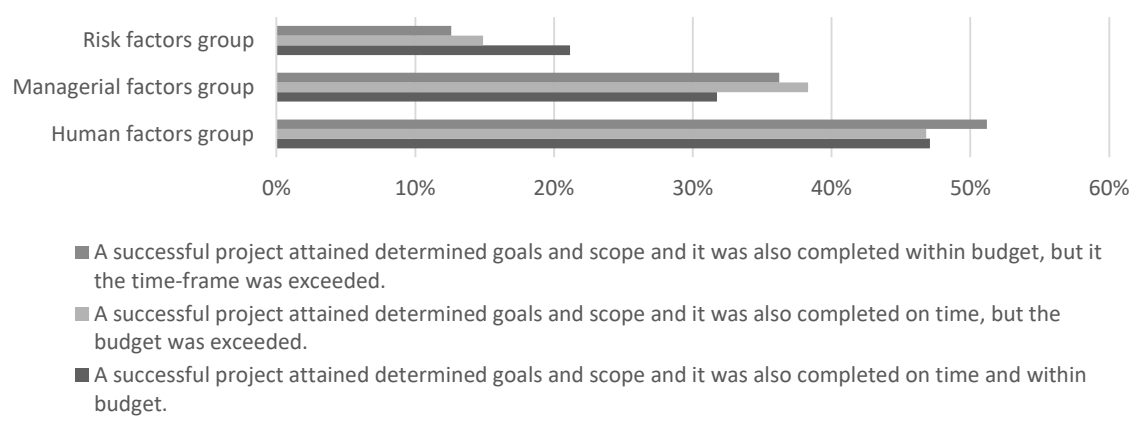

Figure 1. Success Project and Success Factors, $n=118$

Source: own calculations based on the survey data.

Consequently, human factors, which are most intangible and unpredictable, are the key ones even though most managerial factors are given and relatively fixed (such as financial and human resources, scope and requests of the project, etc.) and that risks represent the threats or potential opportunities for the project. Simultaneously, the relative ignorance of the respondents towards the importance of risks and their timely identification and management is assumed.

The group of respondents that perceived the project as successful although the time-frame was exceeded, had the most significant difference between the factors group as human factors take up $51 \%$ of all answers. This could presume a relationship between exceeding the time-schedule and the human factors that could affect it - the better the communication and coherence within the team, the least time exceeded.

The smallest difference between the human and managerial group factors was among the respondents who are tolerant towards exceeding the budget (9\%). As a budget is usually given externally, its relationship with managerial (external) factors is evident. At first, exceeding the budget can only be accepted if allowed by management (sponsor) and it is also very often conditioned by unsuitable financial and human resources assigned from the beginning. Furthermore, an imprecise definition of scope and conditions can easily lead to budget exceeds as well. However, there is also a strong relationship between the human factors and budget exceeds. An incoherent team and miscommunication can influence outputs significantly which may end with higher budget needs.

The group of risk factors included identification, timely management and prevention of risks' activities and gained the lowest number of responses. In times of turbulence and unpredictable development this was a surprising result. It can be assumed that thorough risk management has not yet been 
recognized as an important part of project management in the Czech Republic. This can be linked to the relatively high rate of unsuccessful projects in this field. Insufficient attention to the risks can be identified as one of the main weaknesses and limitations of project management in the Czech Republic.

Successful project definition was also analyzed through its connection to stakeholder demands and requests. This means that the initial, independent groups of respondents were created according to their definition of a successful project. Later in the questionnaire, respondents needed to define and choose different stakeholder demands that were divided into three groups. The same principle of three groups of human, managerial and riskrelated demands and requests was used and respondents were supposed to choose the most relevant ones. The human group included sufficient number of team members as well as approach to working at weekends if needed; the managerial group included following procedures and the rules of the organization and escalation of problems to higher levels of management; the risk group consisted of reaching expected outputs no matter what the risks, as well as acceptance of the project no matter what the conditions.

In order to analyze the connection between the respondents' perception of the successful project and the perception of the main stakeholder demands, these two questions had to be analyzed together. Table 1 shows the weighted averages of groups of stakeholder demands (human, managerial and risk) calculated per the amount of chosen demands (belonging to each group) taking into consideration how the respondents defined a successful project. Values used to convert verbal answers to numerical ones in each group of stakeholders were the following: 1 (human group), 2 (managerial group), 3 (risk group). An example would be that if the respondent firstly defined a successful project as the one that attained determined goals and scope and it was also completed on time and within the budget and then chose a sufficient number of team members as the main stakeholder demand, their answer would be converted to 1 (it represents the human group of main stakeholder demands) and would be included in the first line of the Table 1.

The results show that main stakeholder demands are from the managerial group regardless of how successful a project is defined, as the weighted averages of all three definitions tend to 2 .

Therefore, project managers and teams are primarily expected to follow the procedures and rules of the organization they work for (regardless of the nature of the project) and not to escalate issues to higher levels of management. Considering that decision-making within project teams is quite restricted and projects mostly differ, these demands are difficult to satisfy and cope with. 
Table 1. Main stakeholder demands, $\mathrm{n}=118$

Successful project definition

Weighted average

A successful project attained determined goals and scope and 1.71

it was also completed on time and within budget.

A successful project attained determined goals and scope and 1.,66 it was also completed on time, but the budget was exceeded.

A successful project attained determined goals and scope and $\quad 1.80$ it was also completed within budget, but the time-frame was exceeded.

Source: own calculations based on the survey data.

More to the point, stakeholder demands related to the risks are the least present and least significant which confirms that risks are one of the weaknesses of project management in the Czech Republic.

The identification of problematic areas in relation to the definition of a successful project was analyzed too. Table 2 shows the results obtained. The principle and calculations were performed in the same manner as explained above for the results from Table 1.

Table 2. Problematic areas of the projects, $n=118$

Successful project definition

A successful project attained determined goals and scope and it was also completed on time and within budget.

A successful project attained determined goals and scope and it was also completed on time, but the budget was exceeded.

A successful project attained determined goals and scope and it was also completed within budget, but the time-frame was exceeded.
Weighted average

2.23

1.53

2.21

Source: own calculations based on the survey data.

Problematic areas for approximately $60 \%$ of all respondents tend to belong to the managerial group. The most frequently chosen problematic area in general is vaguely-defined scope of the project by higher management or project sponsor. This result shows certain issues in the cooperation and understanding between the project sponsor and higher management and project team (or project manager). Vaguely-defined scope makes it almost impossible for a project to be successful as the goals and outputs are not clearly defined. Therefore, both sides can have different expectations and understanding of the project. Consequently, this could be another major 
reason for the relatively high rate of unsuccessful projects in the Czech Republic and is another great weakness that should be analyzed and discussed closely.

Conversely, the results show a significant difference between the problematic areas determined by the respondents who perceive the project as successful, although the budget is exceeded, and the rest of the respondents. Most problematic areas tend to belong to the human group and the most frequently chosen were irresponsibility and lack of knowledge of PM methodology. Based on the results, exceeding the budget could be caused or driven by the presence of these areas, or if they are insufficiently or incorrectly handled and solved.

\section{Main characteristics of project management}

Main characteristics can outline the approach used as well as the overall status of project management. This section of the paper also provides valuable information for entrepreneurship in the Czech Republic, especially for innovative start-ups. The trend of high-potential start-ups is growing and entrepreneurial spirit is on the rise. Agile, innovative project management can facilitate a smooth inception and an effective, systematic organizational performance enabling long-term success and sustainability.

As shown in Figure 2, where we see projects reflecting innovation as well, one third of the projects are primarily involved in IT systems, while development of new products/services and process management make up $18 \%$ and $14 \%$ respectively of projects. These areas are important innovation drivers as innovation is one their key components. Therefore, project management is moving in the right direction and there is at least a basic awareness of the necessity and importance of innovation today. In addition to that, $20 \%$ of projects focus on modernizing technical equipment and educational training for employees ( $10 \%$ each). Both factors lead to the sustainable development of any business entity.

Important factor for the identification of a traditional or agile approach is the duration of the project too. A general structure of project duration in the Czech Republic is shown in Figure 3 and was calculated based on the data collected via the survey the authors conducted in 2016.

According to this structure, the majority of projects in the Czech Republic can be considered as medium-term projects. Short-term projects that last up to one year make up $38 \%$ of all projects while $14 \%$ of them are even shorter with a maximum duration of 6 months. This means that, in total, $52 \%$ of projects are not longer than one year.

At the same time, $43 \%$ of projects belong to longer medium-term projects as they last one to three years. There is only a small proportion of long-term projects with a duration of more than three years $(5 \%)$. 


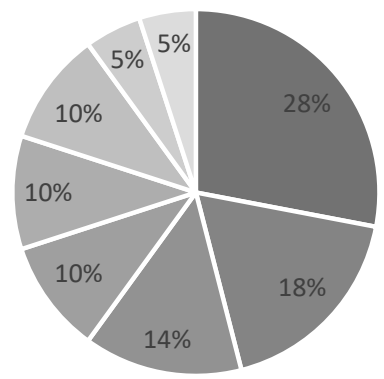

$$
\begin{aligned}
& \text { - IT systems } \\
& \text { - process management } \\
& \text { - educational training }
\end{aligned}
$$

Figure 2. Project areas in the Czech Republic in the last 3 years, $n=118$ Source: own calculations based on the survey data.

If we combine the project areas and project duration in the Czech Republic, projects with the shortest overall duration are reorganization projects $-83 \%$ of projects last up to 12 months. However, according to the research, only $5 \%$ of projects are involved in this area. Average duration of IT projects is approximately one year or shorter. More precisely, $51 \%$ of such projects have duration of $6-12$ months while $28 \%$ last up to three years. Although there is still a significant proportion of IT projects that last up to three years, it is evident that the majority of them are short-term projects, which corresponds with an innovative, flexible and more agile approach. Other types of projects attained similar results. $82 \%$ of projects for the development of new products/ services are approximately one year and only $3 \%$ are up to three years. This corresponds with the need for regular innovations in the market due to rapid changes, increased flexibility and stiff competition.

\section{Usage of project management methods}

The questionnaire contained a complex matrix aimed at identifying the most used methods. We identified 38 effective project management methods (and tools) that could be used in different phases. The respondents were asked to assign methods to just one project-cycle phase due to the technicalities of survey processing although some of them are suitable for more than one phase.

According to the survey responses, Feasibility Study is the most used and probably the most known method. More than half of the respondents used it during the pre-project phase and it is primarily used to show whether the project should be realized or not. 


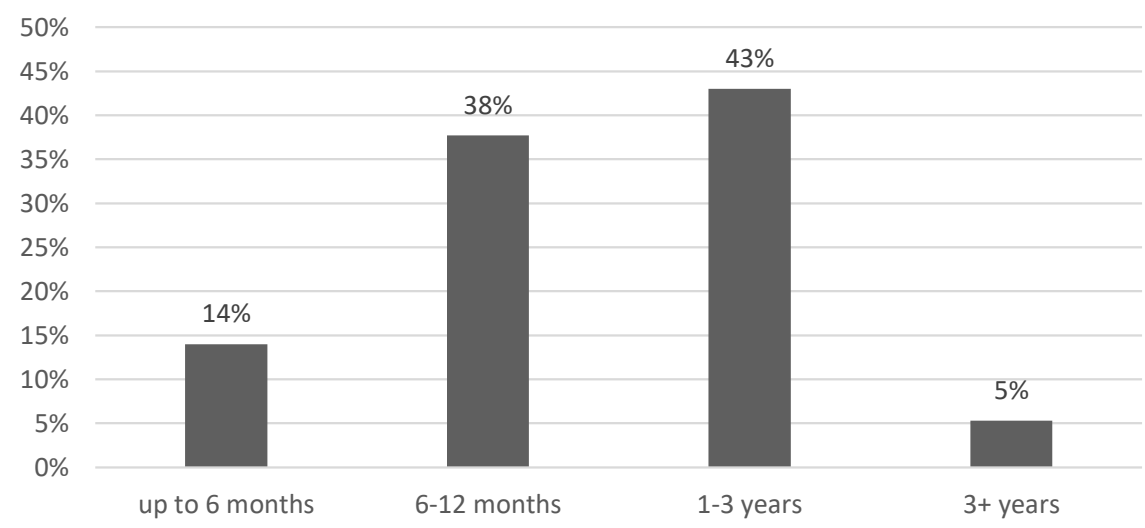

Figure 3. Project duration in the Czech Republic, $n=118$

Source: own calculations based on the survey data.

During the planning phase, Work Breakdown Structure (WBS) is the most extended method. Its popularity has been growing recently thanks to its clear output. Besides being the prevalent method of the planning phase, WBS is the second most used phase out of all 38 methods included in the matrix.

The most accepted method out the 38 , and the most used in the afterproject phase, is the Lessons Learned tool. Almost two thirds of respondents used this tool which indicates its benefit for sharing experience, increasing knowledge, learning from mistakes, as well as preventing the occurrence of negative events that could have been predicted.

\section{DISCUSSION}

The survey showed that stakeholder demands are complex and change significantly, which makes working in project management arduous. This is supported by the results of the survey that showed that, regardless of the projects' success, most complex demands and expectations were from the managerial group, which can be influenced by project managers and teams only up to a certain extent. These expectations have a tendency to be more external and can also be subject to frequent changes, which makes it more complex for project teams to understand and meet them.

Project managers and teams are primarily expected to follow the procedures and rules of the organization they work for (irrespective of the project nature) and not to escalate the issues to higher levels of management. 
At the same time, decision-making within project teams is quite restricted and projects mostly differ: therefore, it is evident that these demands are difficult to satisfy and cope with. This can lead to misunderstandings within the project teams and a mismatch between the expectations and scope defined by the stakeholders and the project teams. Consequently, the results and outcomes of the project might be considered as unsatisfying.

However, this result can have certain limitations because the targeted respondents were project managers and not all stakeholders. This could have led to a biased perspective regarding stakeholder demands and expectations. At the same time, according to the authors' opinions, project managers are mainly influenced by those demands and expectations and their project management experience gives them a sufficiently broad perspective in defining and recognizing the complexity and variety of the demands and expectations they need to meet in order to successfully complete the projects. Therefore, despite certain limitations, the survey shows the complexity of the demands and expectations which results in making the work of project management difficult.

Analysis of the results of the survey, show a prominent relationship and, to some extent, a correlation between understanding (defining) a successful project and identifying the success factors, stakeholder demands and problematic areas that highlight the complexity of working in the field of project management. Furthermore, vaguely-defined scope was identified as the most problematic area and issue influencing project success. This key matter of project management makes it almost impossible for a project to be successful as the goals and outputs are not clearly defined. At the same time, the implementation of project management in many different areas of business is increasing which makes the stakeholders' demands and requests subject to change and even more complex. These results confirm that stakeholder demands are complex and change significantly, which makes working in project management demanding, and it, therefore, confirms H1.1.

There is a general increase in the level of use of basic project management methods. However, the methods that are broadly used are not very advanced and are specific to the projects. Comparison of the results of the different surveys showed that there is an increase in the use of the same project management methods; however, a broader usage has not been proven. Accordingly, H1.3 was partially confirmed. At this point, the result of the questionnaire provides a good area for discussion. It is common practice, at least when we talk about the Czech Republic, that the simplest methods are most widely used. On the one hand, there is a logical explanation; working with such methods requires "only" readily available data, their use is fast, often visually supported with simple tools. In many situations, using simplistic, 
undemanding methods is certainly justified and reasonable. However, they may be - in particular for certain types of project - simplified too much and may distort a situation. Rather often in the Czech Republic the perception is that sophisticated methods are unnecessary because common sense is better and faster. They often cite a lack of time as a reason for not using enhanced PM methods. On the contrary, more complex methods, although they can provide better results (more accurate data, deeper analysis, greater complexity), may not be commonly used in practice.

One of the very strong general trends in PM is agile development. We can see efforts in agile project management development both in publishing and in practical business. Though, taking into consideration the results of the survey regarding the transformation from traditional to agile project management and the basic characteristics of both approaches, it is evident that transformation is present in only a small number of IT organizations, and mostly big multinational corporations.

This means that the overall status of project management in the Czech Republic is still more oriented towards a traditional approach rather than agile, but at the same time it provides great motivation for entrepreneurs, not only in the IT field, to benefit from agile approaches. Moreover, this can also be one of the drivers for project managers and project management experts in the Czech Republic to focus on this type of innovation and use it for improvement in terms of flexibility and timing, as well as making it leaner. However, at this moment, the results dismiss the H1.2.

Agile project management has been a largely discussed topic at many conferences and has been researched in the literature. Despite its popularity as a topic, according to the result of this study, there is no significant increase in the usage of agile project management methods. This was a rather surprising result since it does not correspond with the overall interest for this area of project management worldwide and also in the Czech Republic. Further research could focus on the causes of this outcome. It can be assumed that these causes could have both objective, subjective, emotional, cultural as well as biocritical consequences. At the moment, we can guarantee that the reason for the situation in the Czech Republic is not ignorance of agile development. The first consideration of minor interest is the cultural aspect, as Czechs are relatively conservative and restrained about new things. On the other hand, they are very creative and at the same time rational, which is not at all inconsistent with agile PM. We can assume that a significant reason is a problem in adhering to agile principles. Also, barriers may exist within company politics as well as in the acceptability of all business partners within the project. Overcoming these shortcomings and barriers is the theme for innovative solutions. 
Finally, there are important empirical insights showing the broader implementation of project management, although no essential overall progress was noted in project management in the last 5 years. Thus, project management is a file for innovation.

\section{CONCLUSION}

This study looks at project management from the multi-factor perspective and addresses the current situation by indicating innovative directions of development as well as the broader application of project management methods, which have not been researched much in the region.

Taking into consideration the results of the survey conducted as well as the results of other surveys, it is evident that it is high time for innovation in the field of project management in the Czech Republic.

The study shows that stakeholder demands, related to the risks, are the least present and least significant which leads to projects being very volatile and prone to different risks that are not managed in a timely manner nor prevented. This, being one of the weaknesses of project management in the Czech Republic, shows again clear, urgent need for innovation in project management practices that could lead directly to a lower rate of unsuccessful projects.

Agile methods, as well as innovative, forward-looking methods, are rarely used among the project teams. PM methodology offers a variety of methods for each project phase that could enable an innovative approach to be implemented in project management practices and gradually lead to a substantial increase in project success.

Moreover, there is a link between the definition of a successful project and success factors, stakeholder demands and problematic areas of the project. Project teams are restrained to use a forward-thinking and progressive approach that could enable factors that better influence success and limit the influence of problematic areas.

Basic PM methods, a traditional approach and a static, ignorance of the risk perspective are neither sufficient nor effective in today's project management arena. Agile methodology, risk monitoring and prevention as well as project governance approaches reflecting stakeholder demands and requests, are the new directions project management must head in. This could be a matter of further research in this field too.

These directions will not only improve project management, but will also boost the entrepreneurial spirit and help modern, high-potential start-ups to be competitive in the market. Largely, modernized and innovative project 
management will positively influence all areas of business in the Czech Republic and maintain a better position for stakeholders.

\section{Acknowledgments}

The authors would like to thank the Faculty of Business Administration at the University of Economics in Prague for their financial support through the Internal Grant Agency (IGS 90/2017) as well as the anonymous reviewers for their contribution to this study.

\section{References}

Ali, J., Chew, T.G., \& Tang, T. C. (2004). Knowledge management in agile organizations. Sunway Academic Journal, 1, 13-20.

Booth, W.C., Colomb, G.G., \& Williams, J.M. (2003). The Craft of Research (3rd ed). Chicago: University of Chicago Press.

David, S. Avis. (2008). Leadership styles: An analysis based upon the multifactor leadership questionnaire. Dissertation Thesis. Minneapolis, Minnesota: Capella University.

Doležal, J. et al. (2012). Projektový management podle IPMA, 2. aktualizované a doplněné vydání [Project Management according to IPMA, 2nd ed.]. Prague: Grada Publishing, a.s.

European Commission. (2004). Project Life Cycle Management Guideline. Aid Delivery Methods. Brussels, Belgium: EuropeAid Cooperation Office. Retrieved on 2 February, 2017, from https://ec.europa.eu/europeaid/ sites/devco/files/methodology-aid-delivery-methods-project-cyclemanagement-200403_en_2.pdf

EY \& PMI CZ. (2016). Výsledky průzkumu projektového řizení v České republice a na Slovensku za rok 2015 [Survey Result of Project Management in the Czech Republic and Slovakia for 2015, in Czech]. Retrieved on 2 February, 2017, from http://www.ey.com/Publication

EY. (2013). Průzkum rízení projektů v ČR A SR 2013. [Project Management Survey in the Czech Republic and Slovak Republic 2013, in Czech]. Retrieved on 2 February, 2017, from http://www.ey.com/Publication

Fiala, P. (2004). Projektové rízení modely, metody, analýzy. [Project management models, methods, analyses]. Prague: Professional Publishing.

Gareis, R., Huemann, M., Martinuzzi, A., Weninger, C., \& Sedlacko, M. (2013). Project Management and Sustainable Development Principles. Newton Square, PA: Project Management Institute.

Hanadi, S. (2014). What, when, why and how? A comparison between agile project management and traditional project management methods. International Journal of Business and Management Review, 2(5), 52-74.

Hass, K.B. (2007). The blending of traditional and agile project management. PM World Today, 9(5), 1-8. Retrieved 10 January, 2018, from http://courses.cecs.anu.edu.au/courses/COMP3120/local_docs/ readings/the-blending-of-traditional-and-agile-project-management.pdf 
Hodžić, M. (2016). Analýza současného stavu projektového řízení v České republice [Analysis of the Current State in Project Management in the Czech Republic, in Czech]. Master Thesis. Supervisor Hrůzová, H. Prague: University of Enomics, Prague.

IPMA CZ. (2013). Projektové rízení v ČR 2012. [Project Management in the Czech Republic 212, in Czech]. Retrieved on 2 February, 2017, from http://www.projektmanazer.cz/download?page $=2$

IPMA (2015). Individual Competence Baseline for Project, Programme and Portfolio Management. Version 4.0. Postfach. Zurich: International Project Management Association.

Kerzner, H. (2009). Project Management: A Systems Approach to Planning, Scheduling, and Controlling. Hoboken, New Jersey: John Wiley \& Sons Inc. Khotari, C.R. (2004). Research Methodology. Methods \& Techniques. New Delhi: New Age International Publishing.

Kotler, P.T. \& Keller, K.L. (2011). Marketing Management (14th ed.). New Jersey: Prentice Hall.

Krátký, J., \& Lokaj, J. (2016). Zpráva o výsledcích šetření 2015. [Report on the Results of the Investigation, in Czech]. Retrieved on 2 February, 2017, from http://www.pmconsulting.cz/2016/01/projektove-rizeni-v-cr2015-zprava-o-vysledcich-setreni/

Longman, A., \& Mullins, J. (2005). The Rational Project Manager: A Thinking Team's Guide to Getting Work Done. Hoboken: John Wiley \& Sons.

OGC. (2009). Managing Successful Projects with PRINCE2TM. Norwich: TSO. Owen, R., Koskela, L.J., Henrich, G., \& Codinhoto, R. (2006). Is agile project management applicable to construction? In R. Sacks \& S. Bertelsen (Eds.), Proceedings of the 14th Annual Conference of the International Group for Lean Construction (pp. 51-66).

Santiago, Chile: Ponteficia Universidad Católica de Chile.

PMI. (1996). A Guide to the Project Management Body of Knowledge. Newtown Square, Pennsylvania: Project Management Institute.

PMI. (2000). A Guide to the Project Management Body of Knowledge. (PMBOK ${ }^{\circledR}$ Guide). Newtown Square, Pennsylvania: Project Management Institute.

PMI. (2013). A Guide to the Project Management Body of Knowledge. (PMBOK ${ }^{\circledR}$ Guide) -Newtown Square, Pennsylvania: Project Management Institute.

Pritchard, C. (2009). Project Management Lessonsfrom the Field. Bloomington: iUniverse.

Roberts, P. (2007). Guide to Project Management. Achieving Lasting Benefit Through Effective Change. London: The Economist in association with Progile Books Ltd.

Sauer, C., \& Reich, B.H. (2009). Rethinking IT project management: Evidence of a new mindset and its implications. International Journal of Project Management, 27, 182-193.

SPŘ. (2010). Národní standard kompetencí projektového řízení. Verze 3.1 [National standard competences of project management. Version 3.1]. Brno: Společnost pro projektové rízení. 
The Standish Group International. (2013). CHAOS Manifesto 2013: Think Big, Act Small. The Standish Group International, Incorporated.

Tull, D.S., \& Hawkins, D.I. (1993). Marketing Research: Measurement and Method (6th ed.). New York: Macmillan Publishing Company.

\begin{abstract}
Abstrakt
Znaczenie zarzqdzania projektami stale rośnie, a jego szybki rozwój i sprzyjanie innowacjom sprawiły, że jest on jednym z kluczowych elementów wyników organizacji. Dlatego głównym celem artykułu jest przeprowadzenie systematycznej analizy obecnej sytuacji i praktyk w zakresie zarzqdzania projektami w Republice Czeskiej. Szczegółowo analizowane sq cztery obszary zarzqdzania projektami: główne oczekiwania interesariuszy, główne cechy zarzq̨dzania projektami, poziom wykorzystania metod zarzadzania projektami oraz część identyfikacyjna charakteryzujq̨ca respondentów. Badanie ma charakter eksplanatoryjny i wykorzystuje zarówno pierwotne jak i wtórne dane. Dane pierwotne uzyskano za pomocq internetowego badania przekrojowego składajqcego się z czterech części (identycznych z badanymi obszarami) przeprowadzonych w Republice Czeskiej w 2016 r. Uzyskano 118 odpowiedzi. Badana próba była losowa, ale ekspercka - obejmowała organizacje działajqce w Republice Czeskiej, a respondenci zostali poproszeni o określenie swojego doświadczenia w zakresie zarzqdzania projektami. Ponadto wyniki ankiety autorów porównano z wynikami podobnych badań z ostatnich 5 lat dostarczajqcych dane wtórne. To porównanie przyniosło dodatkowe spostrzeżenia i lepsze zrozumienie teoretycznego uzasadnienia. Wyniki wykazały wyraźnq zależność i do pewnego stopnia korelację między zrozumieniem (zdefiniowaniem) udanego projektu i zidentyfikowanymi czynnikami sukcesu, oczekiwaniami interesariuszy i problematycznymi obszarami wykazujqcymi złożoność pracy $w$ dziedzinie zarzqdzania projektami. Ponadto, niejasno zdefiniowany zakres został zidentyfikowany jako najbardziej problematyczny obszar i problem wpływajgcy na sukces projektu. Ogólnie rzecz biorqc, badanie wskazuje na konieczność innowacji, takich jak opracowanie podstawowych ram dla metod zarzqdzania projektem, jak również zwiększenie wykorzystania dostępnych metod zarzqdzania projektami. Kierunki te nie tylko poprawiq zarzqdzanie projektem, ale również zwiększq ducha przedsiębiorczości i pomogq nowoczesnym, wysoce potencjalnym firmom rozpoczynajqcym działalność w osiagnięciu konkurencyjności na rynku.
\end{abstract}

Słowa kluczowe: zarzqdzanie projektem, metody zarzqdzania projektami, wiedza, interesariusze.

\title{
Biographical notes
}

Majra Hodžić, M.Sc. is a Ph.D. student at the Faculty of Business Administration, University of Economics, Prague. The main focus of her studies is the field of Project Management, primarily the innovative concept of Project Governance. She was awarded a Certificate of Excellence for her Master's Thesis and has already had several publications at international 
conferences. She is also scientific project proposer and leader of the Internal Grant Agency research project "New Trends in Project Management: Project Governance and SROI". Her practical experience working on finance projects, as well as leading an international finance team, contributes to her further development in this field.

Helena Hrůzová, M.Sc., Ph.D., graduated from the University of Economics, Prague (UEP) and participated in certified executive courses at Stanford University and MIT, USA. She is an Assistant Professor and Deputy Head of the Department of Management at the Faculty of Business Administration, UEP. Project Management and Managerial Decision Making are fields of her academic and research interest. Her publishing activity contains more than 200 titles. She is a co-author of an international book published in New York in 2000. She has been awarded several prizes for publications. She has experience in several international researches and is also active in cooperation with different industries. 